\title{
Why Ukraine Surrendered Security: A Methodological Individualist Approach to Nuclear Disarmament \\ By Daniel Gibbs
}

\begin{abstract}
After the breakup of the Soviet Union, Ukraine found itself in possession of the world's third largest nuclear arsenal. By 1994, Ukraine had surrendered its entire nuclear arsenal to its historical enemy, Russia. This phenomenon has largely escaped scrutiny. At a time in world history when the question of nuclear proliferation and disarmament has again come to the forefront of international politics, it is important to reexamine the case of Ukrainian disarmament in which standard paradigms of international relations fail to satisfactorily explain historical events. Only by applying the underutilized individual level of analysis can Ukrainian disarmament be clearly understood.
\end{abstract}

\section{Introduction}

Ukraine not only inherited a nuclear arsenal in 1991, but a new strategic threat: Russia. Ukraine's new nuclear arsenal seemed to be the only effective hedge against the threat posed by its the militarily superior neighbor. Yet the international community, led by the United States and a defeated though still influential Russia, called for Ukraine to surrender its nuclear weapons and join the Non Proliferation Treaty (NPT) as a non-nuclear state. ${ }^{1}$ Despite the real threat from Russia and the deterrent that nuclear weapons provided, Ukraine gave up its strategic nuclear arsenal to Russia in $1994 .^{2}$ Why did Ukraine choose to act in such strategically disadvantageous manner?

In this paper, I argue that this question is best answered through a methodological individualist framework. ${ }^{3}$

${ }^{1}$ Yuri Dubinin, "How Ukraine Became a Nuclear-free State," International Affairs 50, no. 2 (2004): 197-225., 200.

${ }^{2}$ Ibid., 204.

${ }^{3}$ Methodological individualism in political science is not a paradigm with clearly
Contrary to realist and domestic organizational paradigms, I maintain that the significant cause behind Ukraine's policy was the ranking of economic and strategic priorities by its two dominant political actors, Leonid Kuchma and Leonid Kravchuk. The following section provides background. I then challenge the realist perspective by demonstrating the robustness of nuclear deterrent and the existence of a real threat. The final section addresses organizational and individual domestic causes of disarmament.

\section{Background}

Ukraine was a republic in the Soviet Union prior to its breakup in December 1991. In July 1991, the Soviet Union and the United States signed the START-1 treaty, which placed limits upon strategic offensive weapons. When Ukraine left the USSR, it agreed, along with other former Soviet

established parameters. The approach presented in this paper follows a Misesian methodology, outlined in Ludwig von Mises' Theory and History (Auburn, Alabama: LVMI, 2007).

The Agora: Political Science Undergraduate Journal Vol. 2 No. 2 (2012) 
members of the newly formed Commonwealth of Independent States, to guarantee the implementation of international agreements entered into by the Soviet Union. ${ }^{4}$ On May 22, 1992, the leaders of Ukraine, Belarus, and Kazakhstan signed a document known as the "Lisbon Protocol," which established the new nuclear states as signatories to the START treaty and committed them to joining the NPT as non-nuclear states by the time of the treaty's renewal in 1995. ${ }^{5}$ Both of these measures still had to be ratified by the Ukrainian Parliament. ${ }^{6}$

Ukraine initially cooperated with the process of nuclear disarmament, returning its entire tactical nuclear arsenal to Russia by the end of May 1992. ${ }^{7}$ The future of the 1,600 remaining strategic weapons within its borders was complicated by an unexpected policy reversal in December 1992. On December 11, the Ministry of Defense alerted its embassies that Ukraine was announcing its right to the nuclear devices stationed within its border and that the country's leaders needed time to examine all aspects of the nuclear situation before ratifying any international agreements. ${ }^{8}$

Negotiations between Moscow and Kyiv began in January 1993. The Russian delegation's goal was to get Ukraine to fulfill its obligations under the Lisbon Protocol and dismantle its arsenal. Ukraine was hesitant to

\footnotetext{
${ }^{4}$ Dubinin, 204.

5 Ibid., 205.

${ }^{6}$ Officially the Verkhovna Rada or Supreme Council.

${ }^{7}$ Dubinin, 205.

${ }^{8}$ Ibid., 207
}

cooperate, opening negotiations with a provocative proclamation of its unambiguous property right to its nuclear arsenal. The first round of negotiations failed to produce any concrete deal and concluded with Russia informally recognizing Ukraine as a nuclear state. ${ }^{9}$

In the months following this exchange with Russia, the Ukrainian Parliament refused to take up a vote on the ratification of the START treaty. ${ }^{10}$ In April, a draft of legislation that would have banned nuclear weapons from Ukraine was defeated. ${ }^{11}$ Russian President Boris Yeltsin and Ukrainian President Leonid Kravchuk met in September and agreed that all nuclear munitions in Ukraine were to be removed no later than 24 months after ratification of the START treaty. ${ }^{12}$ This agreement collapsed several weeks later when Parliament began the process of voting on START ratification. Despite the pleas of President Kravchuk, Parliament voted down his agreement with Yeltsin. Instead, Parliament passed a heavily amended version of the START treaty in November that directly contradicted the purpose of the treaty. These amendments excused Ukraine from disarmament and again declared the

\footnotetext{
${ }^{9}$ Ibid.

${ }^{10}$ RFE/RL Daily Report, "Newsbriefs on Ukraine," The Ukrainian Weekly, May 9, 1993: 2 .

${ }^{11}$ Ibid.

${ }^{12}$ Steven Pifer, The Trilateral Process: The United States, Ukraine, Russia and Nuclear Weapons, Arms Control Series, Brookings Institute (Brookings, 2011)., 14.
}

The Agora: Political Science Undergraduate Journal Vol. 2 No. 2 (2012) 
weapons stationed in Ukraine to be state property. ${ }^{13}$

In response to the startling and illegal revisions of the START treaty, the presidents of Ukraine, Russia, and the United States met in early December. The "Trilateral Accords," which emerged from the summit, confirmed Ukraine's commitment to join the NPT as a nonnuclear state and to relinquish its nuclear arsenal. ${ }^{14}$ In exchange, Ukraine would receive technical and financial aid for the disarmament process in addition to compensation for highly enriched uranium transferred to Russia. ${ }^{15}$ The details of the Trilateral Accords were worked out during the first half of 1994 and formally signed by the three presidents in May. ${ }^{16}$ In February, Parliament overwhelmingly voted in favor of ratifying the START-1 treaty and Lisbon Protocol without the additional amendments attached the previous November. ${ }^{17}$ Parliament failed to confirm Ukraine's NPT membership at the time but after the February vote, strategic weapons began to be transferred to Russia. ${ }^{18}$

In June, Leonid Kuchma replaced Kravchuk as president. Kuchma was the former Prime Minister and a political opponent of Krachuck but continued the process of moving Parliament toward a final vote on accession to the NPT. On November 16, 1994, Parliament voted 301-8 to join the NPT as an owner of

\footnotetext{
${ }^{13}$ Dubinin, 221

${ }^{14}$ Ibid., 222

${ }^{15}$ Pifer, 22.

${ }^{16}$ Dubinin, 222

${ }^{17}$ Pifer, 25

${ }^{18}$ Ibid.
}

nuclear weapons. ${ }^{19}$ The Lisbon

Protocol and all international negotiations prior to the vote had set Ukraine on course to join the NPT as a non-nuclear state. The United States and Russia got over this last hurdle by having President Kuchma present a revised version of resolution of ratification to Presidents Clinton and Yeltsin prior to the official signing ceremony. ${ }^{20}$ On December 5 , at the U.S. embassy in Budapest, with all three heads of state present, Ukraine officially surrendered its nuclear weapons and became a non-nuclear signatory of the NPT. ${ }^{21}$

\section{Realist Explanation}

\section{Giving Up Deterrence}

The standard realist approach to strategic decision-making interprets a state's actions primarily through the lens of geopolitical security. Scott Sagan summarizes this paradigm, which he referrers to as the "security model" of proliferation. ${ }^{22}$ According to Sagan, assuming nuclear weapons provide deterrence, states exercise nuclear restraint when one of two conditions is met. First, a security guarantee from an ally can ameliorate a perceived threat. Second, the perceived threat can dissolve. ${ }^{23}$ In the Ukrainian case, we

\footnotetext{
${ }^{19}$ Ibid., 26

${ }^{20}$ Ibid., 27

${ }^{21}$ Ibid.

${ }^{22}$ Scott Sagan, "Why do States Build Nuclear Weapons?," International Security 21, no. 3 (1996): 54-86.

${ }^{23}$ Note the relevance of perception over reality. A state need not face a real threat to proliferate or, in Ukraine's case, refuse to give up its arsenal.
}

The Agora: Political Science Undergraduate Journal Vol. 2 No. 2 (2012) 
must establish two things in order to confirm the decision to give up nuclear weapons as applicable to the security model: did Ukraine perceive Russia as a threat and were either of the above threat-alleviating conditions met?

\section{Ukraine justifiably viewed Russia} as a threat to its security in the early 1990s. Relations between the two former Soviet republics had been sour at best for the three centuries prior to Ukrainian independence. Imperial Russia had harbored aspirations to control Black Sea since the reign of Peter the Great. In the 1930s, the Russian dominated USSR instituted agricultural policies in Ukraine that led to the deaths of as many as 6 million ethnic Ukrainians. $^{24}$ During the August 1991 coup attempt in Moscow, hard-line Soviet commanders in Kyiv took possession of strategic sites outside the city and ordered that Ukraine comply with the new regime or face military action. ${ }^{25}$ At the time or independence, the eastern half of Ukraine was, and still is, dominated by ethnic Russians. Against the backdrop of the many ethnic conflicts that followed the breakup of the communist bloc, Ukraine had legitimate concerns about an ethnic minority within its borders backed by a nuclear superpower and traditional enemy. ${ }^{26}$

\footnotetext{
${ }^{24}$ Stephane Courtouis, Nicolas Werth, Panne Jean-Louis, Anderzej Raczsowski, Karel Bartosek and Jean-Louis Margolin, The Black Book of Communism (Cambridge, MA: Harvard, 1999).

${ }^{25}$ Bruce Blair, "Ukraine's Nuclear Backlash," The Brookings Review 11, no. 3 (Summer 1993): 46.

${ }^{26}$ Recall the readiness of the Russians to rush to the aid of Slavic Serbians in 1914.
}

Further fears were stoked by Russia's new majority party, which had strong ultra-nationalist tendencies, epitomized in the bellicose rhetoric of Vladimir Zhirinovsky. In 1993, Zhirinovsky called on Boris Yeltsin to reassert Russia's dominance over Ukraine and other former Soviet republics. $^{27}$ Ukrainian President Kravchuk expressed Ukraine's concerns about Russia in 1993, stating: "some of our neighbors, especially Russia, have political forces which would like to make territorial claims against Ukraine." ${ }^{28}$

The perceived threat from Russia was also expressed by the unwillingness of the Ukrainian Parliament to fulfill its obligations under the Lisbon Protocol in a timely fashion. By early 1993, the majority of public opinion in Ukraine had shifted from being anti-nuclear to pro-nuclear. ${ }^{29}$ In April of that year, as the debate over disarmament began to unfold in Parliament, a deputy of the Ministry of Defense and advisor to Parliament, General Volydymyr Tolubko, proposed the creation of a "nuclear shield" in order to force other nations in the international community respect Ukraine. ${ }^{30}$ Russia would clearly be the implicit target of this shield. On April 22, Parliament voted against unilateral disarmament and postponed the vote to ratify the START

\footnotetext{
${ }^{27}$ Asia Times, "Why Ukraine Should Keep Its Nukes," World Press Review, June 1994: 51.

${ }^{28}$ Bohdan Nahaylo, "The Shaping of Ukrainian Attitudes on Nukes," The Ukrainian Weekly, May 9, 1993: 2, 12. ${ }^{29}$ Taras Kuzio, "Shifting public opinion in Ukraine affects its status as nuclear power," Ukrainian Weekly, May 9, 1993: 7.

${ }^{30}$ Ibid., 2.
}

The Agora: Political Science Undergraduate Journal Vol. 2 No. 2 (2012) 
treaty until July. ${ }^{31}$ Five days prior to this vote, the Chairman of Parliament, Ivan Pliushch, told reporters at a press conference that he agreed with General Tolubko's analysis and that he had observed a significant amount of public support for a nuclear-armed Ukraine. ${ }^{32}$ When Parliament first voted on the START treaty, Prime Minister Kuchma proposed legislation to keep 46 sophisticated SS-24 Russian missiles stationed inside of its territory, a noteworthy indication of how seriously he perceived the importance of possessing a deterrent. ${ }^{33}$

Negotiations between Russia and Ukraine had been in progress since January 1993 but had not progressed beyond the already agreed upon removal of tactical nuclear weapons from Ukraine. The purpose of these talks was to facilitate Ukraine's surrender of its strategic weapons to Russia in return for a "peace dividend" in the form of electricity, and to assure Ukraine's ascent to the NPT in 1995 as a non-nuclear state. ${ }^{34}$ During the negotiations, the Ukrainian delegation was disorganized, uneasy, and secretive. ${ }^{35}$ The Russians on the other hand worked diligently with their counterparts, willing to make large concessions in order to secure the rapid

${ }^{31}$ RFE/RL Daily Report, "Newsbriefs on Ukraine," The Ukrainian Weekly, May 9, 1993: 2.

${ }^{32}$ Bohdan Nahaylo, 2.

33 The Economist, "Ukraine: A New Nuclear State," The Economist, June 12, 1993: 57-58.

${ }^{34}$ Dubinin, 204

35 Ibid., 206
Ukrainian disarmament. ${ }^{36}$ The Russians had a serious incentive to remove the weapons as fast as possible because of the real security threat they posed. The Ukrainians on the other hand were in no rush to surrender their deterrent capability. The best strategic option for Ukrainian with regards to Russia was to be engaged in fruitless negotiations. As long as their delegations were meeting on a regular basis and discussing disarmament, the international community, and Russia in particular, could not credibly accuse Ukraine of seriously considering becoming the world's third largest nuclear power even though this was exactly what politicians in Ukraine were doing. ${ }^{37}$ The fact that Ukraine approached the negotiations in this way suggests the continued perceived threat from Russia. If such a threat were not perceived, Ukraine would have presumably accepted the ample inducements offered by both Russia and America prior much earlier than it did. ${ }^{38}$

\footnotetext{
${ }^{36}$ Ibid. The story of the negotiations told by Yuri Dubinin, former Russian Deputy Foreign Minister, places emphasis on the professionalism and preparedness of the Russian delegation and portrays the Ukrainians as hesitant and almost deliberately stalling the negotiation process. ${ }^{37}$ Borys Klymenko, "Ukraine is no Nuclear Boogeyman," The Ukrainian Weekly, January 17, 1993: 2. "Ukraine's procrastination in ratifying the START I treaty is, very simply, a means for this independent state to protect its own interests."

${ }^{38}$ New York Times, "Ukraine: Barrier to Nuclear Peace," New York Times, January 11, 1993.; Dubinin, 2004.
}

The Agora: Political Science Undergraduate Journal Vol. 2 No. 2 (2012) 
Discussions with the United States during this period revolved around establishing a security guarantee that would be implicitly postured against Russia. ${ }^{39}$ It is questionable whether such a guarantee could be plausibly attained. Extending a credible deterrent during the Cold War to West Germany was remarkably difficult. ${ }^{40}$ Did Ukraine ever seriously expect to attain standing in the eyes of the United States as high as West Germany, especially after the dissolution of the Soviet threat to Western Europe? It was highly probable that any potential conflict between Russia and Ukraine would be viewed as a regional conflict over which the U.S. would be unwilling to risk war with nuclear-armed Russia. In 2008, Georgia enjoyed an implicit security guarantee from the West but was left to fend for itself when Russia invaded South Ossetia and Abkhazia. ${ }^{41}$ Ukrainian policy makers in 1993 could reflect upon the strikingly similar collapse of an implicit guarantee made to Hungary prior to its attempted revolution in 1956.

Throughout 1993, Ukraine sought security guarantees specifically from nuclear powers. The leading Russian newspaper Izvestia effectively summarized Ukraine's wishful endeavor

${ }^{39}$ Eugene Iwanciw, "Is Ukraine to be Secure?," The Ukranian Weekly, January 17, 1993: 2.

${ }^{40}$ Steven Miller, "The Case Against a Nuclear Ukraine Deterrent," Foreign Affairs 72, no. 3 (1993): 67-80., 57.

${ }^{41}$ Triesman Daniel Treisman, The Return: Russia's Journey from Gorbachev to Medvedev (New York, New York: Free Press, 2011). 150-155. to ally itself with the West against Russia: "In Kyiv, they should ... understand that the world community will never agree to examine guarantees of collective security in the sphere of nuclear weapons."42 Moreover, Washington's view of Ukraine during the START-1 negotiations was predominantly that of a Russian satellite and not an independent nuclear state. ${ }^{43}$ The best guarantee Ukraine could possibly hope to attain would be ambiguous and merely tacit. This was hardly a suitable condition to cause Ukraine to surrender its only deterrent.

Thus we see that Ukraine consistently perceived Russia as a real threat to its security and at no point prior to its decision to surrender its arms received a legitimate security guarantee from the West against Russian aggression. Assuming that nuclear weapons are a deterrent, it appears that Ukraine acted against its strategic best interest by unilaterally disarming. Let us now critically examine the deterrence assumption and consider the possibility that Ukraine's decision to disarm was in fact strategically prudent.

\section{Did Ukraine Possess a Deterrent?}

Deterrence is achieved not through the ability to defend but the ability to punish. ${ }^{44}$ The purpose of a

\footnotetext{
${ }^{42}$ Quoted in Borys Klymenko, "Ukraine's Nuclear Arms Negotiator Pleased with Progres on Security," The Ukrainian Weekly, January 17, 1993: 1.

${ }^{43}$ New York Times, "Ukraine: Barrier to Nuclear Peace."; Eugene Iwanciw, "Is Ukraine to be Secure?"

${ }^{44}$ Kenneth Waltz, "Waltz Respondes to Sagan," in The Spread of Nuclear Weapons:
}

The Agora: Political Science Undergraduate Journal Vol. 2 No. 2 (2012) 
state's nuclear arsenal is, in the words of Thomas Schelling, "deterrence ex ante, not revenge ex post." 45 Therefore, in order to function as a deterrent, a state's nuclear arsenal must be capable of surviving a first strike so that it may be deployed in a second strike. ${ }^{46}$ At first glance, the quantitative nuclear imbalance between Russia and Ukraine would appear to render the probability of Ukraine surviving a first strike negligible. However, despite numerical advantage, launching a successful first strike would have been remarkably difficult to carry out. As Kenneth Waltz observes, "if the country attacked has even a rudimentary nuclear capability, one's own severe punishment becomes possible." ${ }^{47}$ When considering whether or not to launch a first strike, Russia would have had to be absolutely confident that it would destroy Ukraine's entire nuclear arsenal, lest a single surviving missile be launched against Moscow. Thus, Waltz concludes, even a small nuclear arsenal possesses a robust deterrent. ${ }^{48}$

Scott Sagan challenges Waltz's confidence in the deterrent force of a small arsenal, arguing that organizational operational routines

A Debate Renewed, 125-155 (New York, New York: W. W. Norton \& Company Inc., 2003).

${ }^{45}$ Ibid., 187.

${ }^{46}$ Kenneth Waltz, "More May Better ," in The Spread of Nuclear Weapons: A Debate Renewed, 3-45 (New York, New York: W. W. Norton \& Company Inc., 2003). 6-8.

${ }^{47}$ Ibid., 19.

${ }^{48}$ Scott Sagan, "More Will Be Worse," in The Spread of Nuclear Weapons: A Debate Renewed, 46-88 (New York, New York: W. W. Norton \& Company Inc., 2003). 69. make a first strike possible. ${ }^{49}$ According to Sagan, "even if apparently invulnerable forces are built, their ability to withstand a first strike will be highly problematic if inappropriate organizational practices and operational routines are maintained." ${ }^{50}$ As an example, he cites the case of the USSR's failure to keep secret its missile installation in Cuba in 1962 after US intelligence analysts identified a standard Soviet pattern of defensive missile batteries stationed around the installation. ${ }^{51}$ If the highly professional and well-funded Soviet military could make such a mistake, it certainly follows that a relatively new and inexperienced military would be just as susceptible to hazardous organizational practices. In the early 1990s, Ukraine possessed an unprofessional and underequipped military. ${ }^{52}$ It is doubtful whether a military that struggled to prevent recruits from dying during training would be able to coordinate its operations to avoid patterned behavior.

Steven Miller provides a further critique of Waltz, enumerating a number of conditions specific to Ukraine that could have undermined its deterrence capability. ${ }^{53}$ Ukraine's proliferation process would have been instantaneous, inevitably resulting in an inexperienced nuclear establishment. Such an inexperienced establishment would have been unlikely to be up to the task of either defending against a first

\footnotetext{
${ }^{49}$ Ibid.

${ }^{50}$ Ibid., 70.

51 Ibid., 67.

${ }^{52}$ Oleg Strekal, "No Way to Run an Army," The Bulletin of Atomic Scientists, January/Febuary 1994: 34.

${ }^{53}$ Miller, 71.
}

The Agora: Political Science Undergraduate Journal Vol. 2 No. 2 (2012) 
strike or launching a successful second strike. Miller also addresses the nuclear relationship between Russia and Ukraine prior to the breakup of the Soviet Union. Miller writes:

"The capabilities and vulnerabilities of Ukraine's nuclear weapons will be known intimately by Russia. [...] Thus, Ukraine would pass through an initial period of substantial nuclear vulnerability_potentially raising a preventative war temptation for Moscow."54

Additionally, Ukraine and Russia share an ambiguous border and a de facto common language. As noted earlier, Ukraine also has a substantial Russian minority within its borders. It was all but inevitable that Russia would have had reliable intelligence on Ukraine's nuclear program via espionage. $^{55}$

These are reasonable objections to the overall strategic operational value of the Ukrainian arsenal. However, these weaknesses were not enough to have rendered the deterrent threat possessed by Ukraine void by enabling a Russian first strike. In response to Sagan's concern about the threat to deterrence posed by organizational routine, Waltz points to the distinction between the complexity of a nuclear arsenal and the simplicity of strategic conditions it creates. ${ }^{56}$ Nuclear weapons eliminate uncertainty about the destructive consequences of conflict. ${ }^{57}$ Moreover, he writes, "States are not likely to run major risks for minor gains." ${ }^{28}$ Assuming a nuclear Ukraine did develop a vulnerable pattern of behavior that the Russians could observe, it does not follow that Russia would launch a preventative strike.

Russia would still have had to accommodate for the probability that a single Ukrainian bomb could be launched in a second strike against Moscow. Even if routine behavior could reduce this probability to less than one percent, the costs of losing Moscow, however quantified in the mind of the Russian President, must be immeasurably greater than the benefits of disarming Ukraine under all but the direst of circumstances. Figure 1 illustrates the strength of a Ukrainian deterrent against a preventative strike.

The conditions necessary to fulfill this criterion are restricted to the perceived imminent threat of a Ukrainian first strike. Since Ukrainian decision makers are bound by the same costbenefit calculation, substituting Kiev for

\section{Figure 1}

Necessary Condition for First Strike:

Benefit of disarming Ukraine $>$ P(failure) $x$ Cost of nuclear counterstrike on Moscow

\footnotetext{
54 Ibid., 73.

${ }^{55}$ Ibid., 74
}

The Agora: Political Science Undergraduate Journal Vol. 2 No. 2 (2012) 
Moscow, such a condition will not come about through rational action since the probability of failure inherently cannot be zero and that states place immeasurability great value on not being the victim of a nuclear strike. Thus even assuming organizational routines, only misperception could increase the benefits of disarming one's opponent above the expected costs of the action. The exogenous threat of misperception is a topic for discussions of nuclear abolition, not the robustness of deterrence, though common language and geographical proximity would presumably mitigate the potential for nuclear misperception.

The same logic applied to Sagan's opposition to deterrence can be applied to Miller's critique of issues specific to Ukraine. Granting Miller both the threat of espionage and the inexperience of Ukraine with an independent nuclear arsenal, Russia's expected cost of a first strike will decline. However, as we have seen, it will hardly decline enough to initiate the decision to launch a full nuclear attack. It is not a given though, that the conditions Miller discusses would have come about. Ukraine's nuclear establishment was inexperienced in 1993, but the inexperience was limited to control over the arsenal. Ukraine's nuclear establishment was subordinate to Russia, not removed from the Soviet nuclear chain of command. If Ukraine had decided to take possession of the weapons on its soil, the only major obstacle to establishing a direct threat to Moscow would be to reroute the target sets for the missile computers. ${ }^{59}$ While

\footnotetext{
${ }^{58}$ Ibid.

${ }^{59}$ Blair, 46.
}

it would have taken the Ukrainian military some time to build a competent nuclear infrastructure, a few experts could target Moscow with 18 ICBMs tipped with 128 warheads in a matter of weeks or months. ${ }^{60}$ The uncertainty surrounding when exactly Ukraine would be able to retarget its missiles and how quickly it could establish a small bomber force would have been enough to deter Russia from attempting a first strike during the period immediately after the Ukrainian seizure of its arsenal.

Finally, it must be observed that Ukraine possessed far fewer nuclear weapons than Russia but still had more than 1,600 strategic warheads at its disposal. ${ }^{61}$ Regardless of whether Ukraine could effectively reprogram its missiles, the country's strategic bomber force could deploy as many as 416 bombs into Russian territory. ${ }^{62}$ Even if Russia could successfully eliminate $90 \%$ of Ukraine's arsenal in a first strike, more than 160 warheads could be launched in a counterstrike. ${ }^{63} \mathrm{~A}$ reexamination of the cost-benefit equation in Figure 1 in light of the sheer size of Ukraine's arsenal, even allowing for all the deficiencies brought against it by Miller and Sagan, illustrates the absurdity of a Russian first strike and the robustness of Ukraine's nuclear deterrent. Thus despite having a nuclear deterrent against a powerful enemy, Ukraine surrendered its nuclear

${ }^{60}$ Mearsheimer, 62.
${ }^{61}$ Christopher Fettweis, "Dividing The Empire: Ukraine, Belarus, Kazakhstan and the Collapse of the Red Army," Issue Brief, University of Maryland (2000), 9.

${ }^{62}$ The Economist, "Nuclear Dreams," The Economist, August 14, 1993: 46-48.

${ }^{63}$ Asia Times, 52.

The Agora: Political Science Undergraduate Journal Vol. 2 No. 2 (2012) 
arsenal to Russia in 1994. The systemic realist-security paradigm, therefore, cannot satisfactorily explain why Ukraine chose to disarm.

\section{Domestic Explanation}

Organizational theories of proliferation pervade the literature on nuclear politics. A common strand of organizational theory highlights the role of the military-industrial-scientific complex as a self-interested advocate of proliferation. Etel Solingen and Jeffrey Hymans have advanced notable modifications of this theory, stressing economic and nationalistic concerns of coalitions outside of the militaryindustrial complex. ${ }^{64}$ If not outright endorsed as the robust cause of proliferation, the organizational viewpoint is frequently presented as at least one of many potential causal factors. In the case of Ukraine, however, the best explanation does not emanate from an organizational view but rather from an individual paradigm based on the priority of ends sought by Kuchma and Kravchuk.

\section{Problems with Organizational Theory}

In 1993, organizations and parliamentary coalitions were relatively weak in Ukraine. The nuclear militaryindustrial complex was altogether nonexistent due to Russia's management of the pre-independence

${ }^{64}$ Etel Solingen, "The Political Economy of Nuclear Restraint," International Security, Fall 1994: 126-169.; Jacques Hymans, "Of Gauchos and Gringos: Why Argentina Never Wanted the Bomb and the United States Thought it Did," Security Studies, Spring 2001: 153-185. nuclear program. Moreover, the military was disorganized, underfunded, and disconnected from the political process, which was dominated the President. As noted earlier, General Tolubko publically supported the maintenance of a nuclear deterrent against Russia. His opinion was noticeably influential through its temporary effect on members of Parliament before the April 1993 vote over outright nuclear abolition on Ukrainian soil. The Minister of Defense, Kostyantyn Morozov, on the other hand was one of the most vocal opponents of a nuclear Ukraine. ${ }^{65}$ As early as fall 1992, he lectured Members of Parliament on the prohibitively large cost of taking full control of the arsenal. ${ }^{66}$ He too, like Tolubko, had only a marginal impact on Ukraine's nuclear policy. His military doctrine was largely ignored by Kravchuk and was defeated in Kuchma's Parliament. ${ }^{67}$ Thus it cannot be claimed that the military was a unified, influential organization that guided Ukraine's decision to disarm for strategic reasons.

Similarly, political coalitions lacked the cohesion and power necessary to influence policy from an organizational perspective. Party affiliation was fleeting in the early years of independence and the life spans of coalitions could be measured in days. ${ }^{68}$ Political parties were poorly funded and consequently lacked the resources to

\footnotetext{
${ }^{65}$ The Economist, "Heels Dug In," The Economist, January 9, 1993: 46.

${ }^{66}$ Ibid.

${ }^{67}$ Ibid.

${ }^{68}$ Andrew Wilson and Artur Bilous, "Political Parties in Ukraine," Europe-Asia Studies 45, no. 4 (1993): 693-703.
}

The Agora: Political Science Undergraduate Journal Vol. 2 No. 2 (2012) 
mobilize collective action. ${ }^{69}$ Even the largest parties had nationwide membership rosters of less than 12,000 and the public was generally ignorant of both the ideology and activities of parties. ${ }^{70}$ For the most part, members of Parliament voted as individuals and not in unified blocks. ${ }^{71}$

The absence of any unified organization in Ukraine presents a problem for any organizational theory of disarmament, as the critical unit of analysis is not present. While both economic interest and nationalism were surely applicable to individual decisions made by members of Parliament, there was no self-interested, organized group capable of molding a consistent national policy.

\section{Two Rivals Merge}

While organizations carried little power in Ukraine, the President and Prime Minister were able to influence policy by coalescing temporary support around their relatively consistent positions. Since party structure did not function as an effective mechanism for facilitating bloc voting, individual members of parliament sought this alternative, transient means of forming consensus. However, it is easy to play up the role that the Parliament truly played in the process of influencing strategic policy. The atomistic party structure of Ukraine opened a power

\footnotetext{
${ }^{69}$ Ibid., 694

${ }^{70}$ Ibid.

${ }^{71}$ Ibid., 695; Lucan Way, "Rapacious individualism and political competition in Ukraine, 1992-2004," Communist and PostCommunist Studies 38, no. 2 (June 2005):
} 191-205. vacuum that was filled by the executive branch. ${ }^{72}$ Faced with the parliamentary modifications made to the Trilateral Accords in 1994, President Kuchma bypassed the official language of the accords ratified by the Ukrainian

Parliament and signed the document as it had been written by Kravchuk with the leaders of Russian and the US. Such a display of executive control suggests that once Ukraine's two most powerful politicians accepted disarmament as inevitable, ratification by Parliament was reduced to mere formality.

Both Prime Minister Kuchma and President Kravchuk were strongly in favor of an independent Ukraine. Their visions for the country's future diverged over whether Ukraine would face East or West. Kravchuk saw Ukraine as a future European nation integrated into the Western international community. ${ }^{73}$ Kuchma on the other hand saw good relations with Russia as the key to the future of Ukraine's economic success. ${ }^{74}$ Despite fundamental political disagreement, their priorities regarding economic and military security were arranged identically. We have already seen that if Ukraine had chosen to keep its weapons, it would possess a robust deterrent and face no direct military consequences. However, becoming a nuclear state would be viewed as a belligerent act by both the United States and Russia. It was highly likely that the decision to go nuclear would have had significant economic consequences for

\footnotetext{
${ }^{72}$ Wilson and Bilous, 695.

${ }^{73}$ Taras Kuzio, "Kravchuk to Kuchma: The Ukrainian presidential elections of 1994,"

Journal of Communist Studies and Transition Politics, 1996., 127

${ }^{74}$ Ibid., 128
}

The Agora: Political Science Undergraduate Journal Vol. 2 No. 2 (2012) 
Ukraine. These included the severing of IMF loans, a suspension of direct foreign aid, an end to Russian oil subsidies, possible sanctions, and general distrust by Western firms who were liable to view Ukraine as an unsafe destination for investment. ${ }^{75}$ Since Ukraine was suffering from a devastating economic collapse in the early 1990's, the economic cost of maintaining a nuclear arsenal would have been exceptionally high.

Kuchma did not seek good relations with Russia for the sake of good relations with Russia. However, he was a strong proponent of Ukrainian independence and saw close ties with Russia as the most secure path to longterm autonomy. IMF aid was frequently contingent upon fulfilling political requirements mandated by the United States. ${ }^{76}$ Moreover, this aid was only temporary assistance, not long-term economic integration. Russia had the potential to aid Ukraine through real mutual economic cooperation based on geographical proximity, common language, and comparative advantage. Kuchma's desire for good relations with Russia can therefore be imputed back to his desire for a prosperous, independent Ukraine.

Similarly, Kravchuk's want of good relations with the West was also rooted in concerns about economic wellbeing. The West offered immediate aid while Russia toiled under the same

\footnotetext{
${ }^{75}$ See Solingen.

${ }^{76}$ Randall Stone, Lending Credibility: The International Monetary Fund and the PostCommunist Transition (Princeton, New Jersey: Princeton University Press, 2002)., 116-207.
}

economic crisis that enveloped Ukraine. The political strings attached were largely limited to fighting corruption and developing democratic institutions, reforms that were likely to take place in Ukraine regardless of Western prodding. Moreover, in the rapidly globalizing world economy of the 1990s, the potential for experienced Western firms to begin doing business in the Former Soviet Union had improved.

Thus we see that the two most significant leaders in Ukraine agreed that the economic cost of nuclear weapons exceeded the military benefit, albeit for different reasons. Had this not been the case, Kravchuk would not have persistently worked to disarm throughout 1993 and Kuchma would not have so seamlessly followed through with the disarmament plan in 1994. Nor would he have supported it in his powerful position as Prime Minister in the last months of 1993. Figure 2 illustrates the logic of action pertaining to nuclear disarmament. Both leaders appear to have valued the military benefits of an arsenal as greater than the cost (Figure 2,1). Their statements in favor of a nuclear deterrent and willingness to consider publically and diplomatically the possibility of becoming a nuclear state evidence this. However, the economic costs of a nuclear deterrent were greater than the economic benefits (or lack thereof) (Figure 2, 2). The relative weight given to economic over military considerations is revealed a posteriori by the decision to surrender a robust deterrent (Figure $2,3)$. In line 4 , the two categories of cost benefit analysis and their relative weight are used to construct an ordinal value schedule where $S_{E}$ and $S_{M}$ refer to economic security and military security

The Agora: Political Science Undergraduate Journal Vol. 2 No. 2 (2012) 


\section{Figure 2}

$$
\begin{aligned}
& \mathrm{C}_{\mathrm{M}} \text { (Nuclear Weapons) }<\mathrm{B}_{\mathrm{M}} \text { (Nuclear Weapons) } \\
& \mathrm{C}_{\mathrm{E}} \text { (Nuclear Weapons) }>\mathrm{B}_{\mathrm{E}} \text { (Nuclear Weapons) } \\
& \mathrm{C}_{\mathrm{E}}>\mathrm{B}_{\mathrm{M}} \\
& \left(S_{E}, S_{M}\right)>\left(S_{E}, \bar{S}_{M}\right)>\left(\bar{S}_{E}, S_{M}\right)>\left(\bar{S}_{E}, \bar{S}_{M}\right)
\end{aligned}
$$

respectively. ${ }^{77}$ That is, both men preferred economic and military security but when confronted with a choice between the two, preferred economic to military security.

Over the course of 1992 and early 1993, Kuchma and Kravchuk examined the possibility of the first best choice. After recognizing its impossibility in mid-1993, they began to pursue the second best outcome, which subsequently shaped Ukraine's policy. Kravchuk appears to have abandoned the prospect of having both economic and military security before Kuchma. In June 1993, Kravchuk appealed to Parliament to ratify START and disarm while Kuchma suggested keeping several missiles. ${ }^{78}$ By February 1994 , Kuchma was staunchly in favor of disarmament and the implementation of disarmament policy followed as president.

Before concluding, one note of clarification should be made with regards to methodology. It should be

\footnotetext{
${ }^{77}$ Bars denote negation.

${ }^{78}$ New York Times, "Ukrainian Official Backs U.S. Plan on Atom Arms," The New York Times, June 7, 1993. ; New York Times, "Ukrainian Parliament Edges Closer to Atomic Disarmament," The New York Times, February 4, 1994. I
}

noted that the ordinal value ranking is what is causally significant. The causality of the subjective value scale itself cannot be known either a priori or a posteriori. It is unknown to the observer what any actor's value scale is ex ante. ${ }^{79}$ Experience allows the observer to infer, through the inferential logic of action, how actors ranked certain ends at a given time. ${ }^{80}$

${ }^{79}$ It is also very possible for actors themselves not to know the reasons behind their value scales or what their value scales specifically are at any point in the past. Any individual who disputes this should consider a past decision and try to produce a perfectly true explanation of why this decision was made. It is possible for Kuchma and Kravchuk to read this paper, dispute the claim, and also be wrong even though they are the subjects whose actions are in question.

${ }^{80}$ See Hans Hoppe, Praxeology and Economic Science (Auburn, Alabama: LVMI, 1988).; Ludwig von Mises, Theory and History (Auburn, Alabama: LVMI, 2007).; Ludwig von Mises, Human Action (New Haven: Yale University Press, 1949).; Murray Rothbard, "Praxeology: The Method of Austrian Economics," in The Foundations of Modern Austrian Economics, 19-39

(Kansas City, Missouri: Sneed and Ward, 1976). Such an approach applied to political science, which stresses causal significance at

The Agora: Political Science Undergraduate Journal Vol. 2 No. 2 (2012) 
Conclusion

\author{
I have presented a causal \\ explanation of Ukraine's disarmament \\ from a domestic level methodological \\ individualist perspective. The \\ fragmentation of coalitions in Ukraine \\ during the debate on nuclear \\ disarmament poses a serious challenge \\ to any organizational politics theory. \\ Additionally, a systemic realist \\ perspective cannot explain nuclear \\ rollback in Ukraine. As I have \\ demonstrated, Ukraine's arsenal was a \\ sufficient deterrent despite its structural \\ shortcomings. The broad significance of \\ this paper is its demonstration of the \\ potential strength of individualist \\ approaches to political science when \\ more readily applied paradigms fall \\ short.
}

the systemic or at least organizational level, requires further elaboration in a future paper. As mentioned in an earlier endnote, the present case is effectively explained by a case-by-case methodological individualist/subjective utility approach outlined by Mises in Theory in History.

The Agora: Political Science Undergraduate Journal Vol. 2 No. 2 (2012) 


\section{Bibliography:}

Asia Times. "Why Ukraine Should Keep Its Nukes." World Press Review, June 1994: 51-52.

Blair, Bruce. "Ukraine's Nuclear Backlash." The Brookings Review 11, no. 3 (Summer 1993): 46.

Charles, Wise, and Brown, Trevor. "The Internal Development of the Ukrainian Parliament." Public Administration and Development 16 (1996): 265-279.

Cortois, Stephane, Werth, Nicolas, Panne, Jean-Louis, Raczsowski, Anderzej, Bartosek, Karel and Margolin, Jean-Louis. The Black Book of Communism. Cambridge, MA: Harvard University Press, 1999.

Dean, James. "Ukraine: Europe's Forgotten Economy." Challenge, November/December 2000: 93-108.

Dubinin, lu. "How Ukraine Became a Nuclear-free State." International Affairs 50, no. 2 (2004): 197-225.

Fettweis, Christopher. "Dividing The Empire: Ukraine, Belarus, Kazakhstan and the Collapse of the Red Army." Issue Brief, University of Maryland, 2000.

Hoppe, Hans. Praxeology and Economic Science. Auburn, Alabama: LVMI, 1988.

Hymans, Jacques. "Of Gauchos and Gringos: Why Argentina Never Wanted the Bomb and the United States Thought it Did." Security Studies, Spring 2001: 153-185.

Iwanciw, Eugene. "Is Ukraine to be Secure?" The Ukranian Weekly, January 17, 1993: 2.

Klymenko, Borys. "Ukraine is no Nuclear Boogeyman." The Ukrainian Weekly, January 17, 1993: 2.

—. "Ukraine's Nuclear Arms Negotiator Pleased with Progres on Security." The Ukrainian Weekly, January 17, 1993: 1.

Kuzio, Taras. "Kravchuk to Kuchma: The Ukrainian presidential elections of 1994." Journal of Communist Studies and Transition Politics, 1996: 117-144.

—. "Shifting public opinion in Ukraine affects its status as nuclear power." Ukrainian Weekly, May 9, 1993: 7.

The Agora: Political Science Undergraduate Journal Vol. 2 No. 2 (2012) 
Mearsheimer, John. "The Case for a Nuclear Deterrent ." Foreign Affairs 72, no. 3 (1993): 50-68.

Menger, Carl. Investigations into the Method of the Social Sciences. New York, New York: New York University Press, 1985.

Miller, Steven. "The Case Against a Ukrainian Nuclear Deterrent." Foreign Affairs 72, no. 3 (1993): 67-80.

Mises, Ludwig von. Human Action. New Haven: Yale University Press, 1949.

—. Theory and History. Auburn, Alabama: LVMI, 2007.

Nahaylo, Bohdan. "The Shaping of Ukrainian Attitudes on Nukes." The Ukrainian Weekly, May 9, 1993: 2, 12.

New York Times. "Ukraine: Barrier to Nuclear Peace." New York Times, January 11, 1993.

—. "Ukrainian Official Backs U.S. Plan on Atom Arms." The New York Times, June 7, 1993.

—. "Ukrainian Parliament Edges Closer to Atomic Disarmament." The New York Times, February 4, 1994.

Pifer, Steven. The Trilateral Process: The United States, Ukraine, Russia and Nuclear Weapons. Arms Control Series, Brookings Institute, Brookings, 2011.

RFE/RL Daily Report. "Newsbriefs on Ukraine." The Ukrainian Weekly, May 9, 1993: 2.

Rothbard, Murray. "Praxeology: The Method of Austrian Economics." In The Foundations of Modern Austrian Economics, by Edwin Dolan, 19-39. Kansas City, Missouri: Sneed and Ward, 1976.

Sagan, Scott. "Why do States Build Nuclear Weapons?" International Security 21, no. 3 (1996): 54-86.

-. "More Will Be Worse." In The Spread of Nuclear Weapons: A Debate Renewed, by Scott Sagan and Kenneth Waltz, 46-88. New York, New York: W. W. Norton \& Company Inc., 2003.

Solingen, Etel. "The Political Economy of Nuclear Restraint." International Security, Fall 1994: 126-169.

Stone, Randall. Lending credibility: the International Monetary Fund and the postcommunist transition. Princeton, New Jersey: Princeton University Press, 2002.

The Agora: Political Science Undergraduate Journal Vol. 2 No. 2 (2012) 
Strekal, Oleg. "No Way to Run an Army." The Bulletin of Atomic Scientists , January/Febuary 1994: 34.

Thames, Frank. "Party and Personal Preference in Post-Soviet Legislatures." Social Science Quarterly 85, no. 2 (2004): 478-496.

The Economist. "Ukraine: A New Nuclear State." The Economist, June 12, 1993: 57-58.

—. "Heels Dug In." The Economist, January 9, 1993: 46.

—. "Nuclear Dreams." The Economist, August 14, 1993: 46-48.

Treisman, Daniel. The Return: Russia's Journey from Gorbachev to Medvedev. New York, New York: Free Press, 2011.

Waltz, Kenneth. "More May Better." In The Spread of Nuclear Weapons: A Debate Renewed, by Scott Sagan and Kenneth Waltz, 3-45. New York, New York: W. W. Norton \& Company Inc., 2003.

—. "Waltz Respondes to Sagan." In The Spread of Nuclear Weapons: A Debate Renewed, by Scott Sagan and Kenneth Waltz, 125-155. New York, New York: W. W. Norton \& Company Inc., 2003.

Whitmore, Sarah. State-Building in Ukraine: The Ukrainian Parliament 1993-2003. New York, New York: Routledge, 2004.

Wilson, Andrew, and Artur Bilous. "Political Parties in Ukraine." Europe-Asia Studies 45, no. 4 (1993): 693-703.

The Agora: Political Science Undergraduate Journal Vol. 2 No. 2 (2012) 